\title{
PELATIHAN BERBAHASA INGGRIS UNTUK WARGA SEKITAR OBJEK WISATA DESA PASIR PUTIH LOMBOK
}

\author{
Nur'azizah ${ }^{1}$, Amsaden$^{2}$, Sapa'atun Jumalia ${ }^{3}$, Aditya Yogasmara $^{4}$, Nurhaolida $^{5}$, \\ Aurelius R.L. Teluma ${ }^{6 *}$ \\ 1,2,3,4,6Program Studi IImu Komunikasi Universitas Mataram \\ ${ }^{5}$ Program Studi Pendidikan Matematika Universitas Mataram \\ *email: aureliusteluma@unram.ac.id
}

\begin{abstract}
ABSTRAK. Penduduk desa Pasir Putih yang tinggal di pesisir pantai Selong Belanak menggantungkan nafkah hidup dari pekerjaan nelayan serta pariwisata pantai. Pantai dan desa ini terletak di pesisir selatan kecamatan Praya Barat, Kabupaten Lombok Tengah, NTB. Terdapat beberapa masalah yang dihadapi masyarakat setempat yakni: 1) Rendahnya kesadaran terkait pentingnya pendidikan terutama Bahasa Inggris di daerah pariwisata; 2) Lemahnya kemampuan berbahasa Inggris di daerah pariwisata dengan potensi yang besar; 3) Masyarakat tidak mampu mengembangkan usaha di daerah pariwisata tersebut karena kemampuan berbahasa Inggris yang tidak memadai; 4) Pendapatan masyarakat rendah. Untuk itu, PKM Pekan Baris merumuskan solusi alternatif sebagai berikut: 1) Memberikan penyuluhan akan pentingnya pendidikan dan peningkatan kemampuan berbahasa Inggris; 2) Melakukan pelatihan berbahasa Inggris bagi masyarakat Desa Pasir Putih, Lombok Tengah; 3) Memberikan pelatihan berbahasa Inggris dengan materi yang berorientasi pada usaha yang sudah dikembangkan, namun tidak berkembang dan usaha baru yang dapat dikembangkan; 4) Meningkatkan keberagaman usaha dengan memanfaat peluang yang ada, seperti guide, menyewakan alat surfing dan meyediakan jasa pelatihan surfing, usaha souvenir yang merupakan karya masyarakat setempat. dan usaha yang kami bentuk dalam keberlanjutan program yaitu usaha pijat. Target luaran Pekan baris antara lain: 1) Terbentuknya kelompok pelatihan bahasa Inggris di desa Pasir Putih Selong Belanak; 2) Laporan Kemajuan dan Laporan Akhir pelaksanaan PKM Pekan Baris; 3) Artikel ilmiah tentang pelaksanaan pelatihan bahasa Inggris bagi warga pesisir pantai Selong Belanak. Metode pelaksanaan dilaksakan dengan pelatihan langsung atau praktik speaking dengan pembagian kelompok belajar sesuai umur dan kebutuhan percakapan di wilayah pantai.
\end{abstract}

Kata Kunci: Pelatihan bahasa Inggris, Desa Pasir Putih, Pantai Selong Belanak

ABSTRACT. The residents of Pasir Putih village who live on the coast of Selong Belanak depend their livelihood on the work of fishermen and coastal tourism. This beach and village is located on the south coast of the Praya Barat sub-district, Central Lombok Regency, NTB. There are several problems faced by local communities, namely: 1) Low awareness regarding the importance of education, especially English in tourism areas; 2) Weak English language skills in tourism areas with great potential; 3) The community is unable to develop business in the tourism area because of inadequate English language skills; 4) Low community income. For this reason, PKM Pekan Baris formulates alternative solutions as follows: 1) Providing information on the importance of education and improving English language skills; 2) Conducting English language training for the people of Pasir Putih Village, Central Lombok; 3) Providing English-language training with 
business-oriented material that has been developed, but not developed and new businesses can be developed; 4) Increasing the diversity of businesses by utilizing the opportunities that exist, such as guides, renting surfing equipment and providing surfing training services, souvenir businesses that are the work of local communities. and the effort we form in the sustainability of the program, namely the massage business. The target line for the Week line includes: 1) Establishment of an English language training group in the village of Pasir Putih Selong Belanak; 2) Progress Report and Final Report on PKM Week Line implementation; 3) Scientific articles about the implementation of English language training for residents of the coast of Selong Belanak. The implementation method is carried out by direct training or speaking practice with the distribution of study groups according to age and conversation needs in the coastal area.

Keyword: English training, Pasir Putih Village, Selong Belanak Beach

\section{PENDAHULUAN}

Penduduk desa Pasir Putih yang tinggal di pesisir pantai Selong Belanak menggantungkan nafkah hidup dari pekerjaan nelayan serta pariwisata pantai. Pantai Selong Belanak, desa Pasir Putih terletak di pesisir selatan kecamatan Praya Barat, Kabupaten Lombok Tengah. Jarak tempuh dari kampus Universitas Mataram, kota Mataram, mencapai 1,5-2 jam dengan kendaraan bermotor dengan kondisi jalan beraspal yang cukup sempit dan bergelombang. Kondisi ini semakin menantang perjalanan dengan jalurnya yang berbukit-bukit dan berkelok-kelok.

Kondisi lingkungan fisik Desa Pasir Putih yang terletak di pesisir pantai Selong Belanak secara umum masih memprihatinkan dikarenakan masih rendahnya tingkat kebersihan dilingkungan sekitar pantaidan pemukiman warga ditambah dengan lemahnya perhatian pemerintah terhadap desa yang jaraknya cukup jauh dari perkampungan Praya Barat. Bahkan, berdasarkan observasi awal yang kami lakukan, kami hanya menemukan satu tempat pembuangan sampah yang disediakan dengan tiga bak sampah berukuran sedang. Apabila pemerintah belum menjangkau masyarakat Desa Pasir Putih, dikhwatirkan baik dari wisatawan maupun dari penduduk sekitar tidak mampu mempertahankan kebersihan pantai dan jika pantai Selong Belanak telah tercemar oleh sampah yang dari masyarakat sekitar maupun wisatawan maka itu akan menjadi faktor wisatawan enggan berkunjung dan tentu akan berdampak terhadap masyarakat sekitar yakni dalam bidang ekonomi.

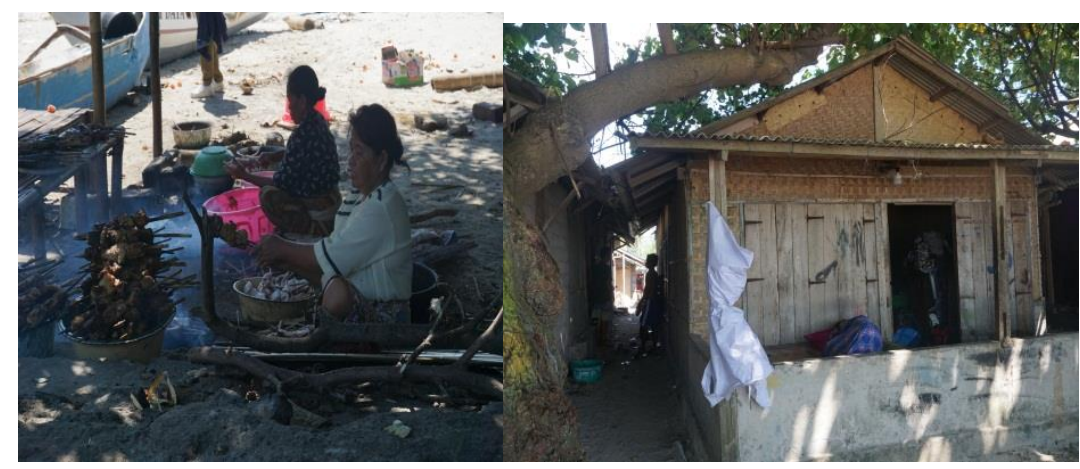

Gambar 1. Kondisi pemukiman \& kegiatan warga pesisir pantai Selong Belanak

Gambar di atas merupakan potret pemukiman masyarakat di Desa Pasir Putih yang berprofesi sebagai nelayan. Kondisi pemukiman masyarakat sangat memprihatinkan, posisi antara 
rumah warga yang satu dengn yang lainnya sangat berdempetan dan bahkan saling berhimpitan, hanya terdapat lorong kecil yang dapat dilewati sebagai satu-satunya jalan apabila ingin melihat rumah warga dibagian tengah. Kondisi sebagian besar rumah warga pada nyatanya tidak layak pakai karena hal tersebut desebabkan oleh pendapatan masyarakat jauh dari yang diharapkan.

Pendapatan yang minim tersebut hanya digunakan untuk memenuhi kebutuhan sandang dan pangan. Hal tersebut membuktikan bahwa masyarakat di Desa Pasir Putih pantai Selong Belanak hidup dalam kemiskinan, padahal Desa Pasir Putih memiliki potensi yang sangat besar untuk kehidupan mereka, di antaranya adalah memanfaatkan letak strategis pemukiman mereka yang berada di pesisir pantai yang banyak didatangi wisatawan, terutama wisatawan asing. Namun, karena minimnya pendidikan masyarakat baik pendidikan secara umum maupun dalam berbahasa Inggris sangat rendah.

Dengan demikian, program kegiatan PEKAN BARIS ini menjadi program edukasi yang diharapkan dapat terlaksana baik sebagai wujud kepedulian kita sebagai makhluk sosial maupun sebagai upaya yang diharapkan meningkatkan Sumber Daya Manusia masyarakat Desa Pasir Putih untuk menghapus kemiskinan.

\section{ANALISIS PERMASALAHAN}

Berdasarkan hasil pengamatan dan wawancara dengan penduduk setempat, diperoleh beberapa masalah konkrit yang dihadapi masyarakat pesisir pantai Selong Belanak terkait pariwisata dan kemampuan bahasa Inggris.

1) Rendahnya kesadaran terkait pentingnya pendidikan terutama Bahasa Inggris di daerah pariwisata

2) Lemahnya kemampuan berbahasa Inggris di daerah pariwisata dengan potensi yang besar

3) Masyarakat tidak mampu mengembangkan usaha di daerah pariwisata tersebut karena kemampuan berbahasa Inggris yang tidak memadai

\section{METODE PELAKSANAAN}

Metode pengembangan yang akan dilakukan merupakan sebuah rangkaian tahapan yang disusun secara sistematis, berikut adalah gambaran flow map yang akan berjalan:

Bagan 1. Metode Pelaksananan Kegiatan Pengabdian PEKAN BARIS

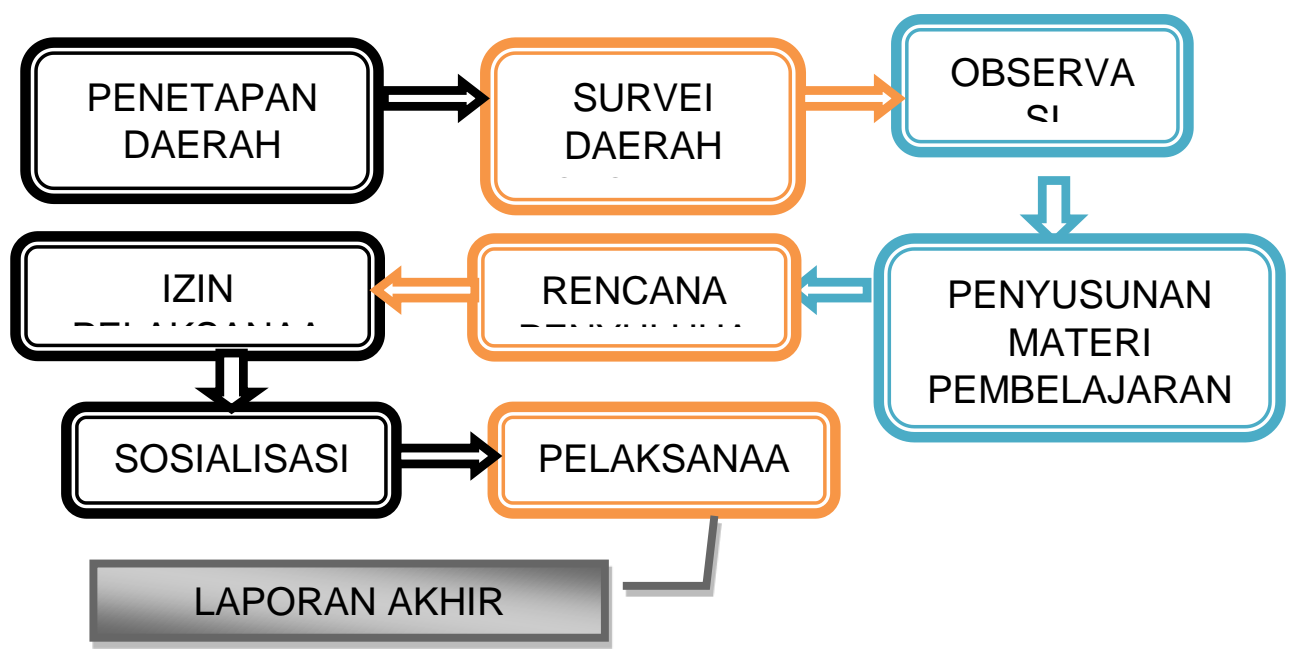


Flow map di atas dapat diuraikan sebagai berikut :

1. Penetapan daerah sasaran: Penetapan daerah sasaran dilakukan melalui rapat anggota untuk menyatukan persepsi dan tujuan tempat pelaksanaan program PKM-M ini, selain itu sumber informasi kami untuk penetapan daerah tersebut berdasarkan data pada internet, daerah yang berpotensi sangat bagus untuk pengembangan pariwisata berada di Desa Pasir Putih, kecamatan Praya Barat, kabupaten Lombok Tengah, provinsi Nusa Tenggara Barat, namun daerah ini masih minim untuk pengembangan kemampuan berbahasa Inggris, sehingga daerah ini sesuai dengan tujuan program pkm m pekan baris.

2. Survei daerah sasaran: bertujuan untuk mengetahui indikator yang menjadi permasalahan setempat yang dapat diselesaikan melalui program yang akan diterapkan oleh PEKAN BARIS bagi masyarakat sekitar objek pariwisata SELONG BELANAK..

3. Observasi lapangan : Melakukan pengamatan secara langsung terhadap penduduk di Desa Pasir Putih, kegiatan ini juga bertujuan untuk melihat latar belakang pendidikan dan kondisi perekonomian masyarakat secara lebih detail dan sebagai alternatif yang digunakan oleh kelompok untuk melakukan pendekatan dengan masyarakat yang akan menjadi sasaran pelatihan.

4. Penyusunan materi pembelajaran dan penyuluhan: kegiatan ini bertujuan untuk menyusun modul dan bahan ajar yang akan menjadi acuan untuk melaksanakan program, penyusunan modul dan bahan ajar ini dilakuan melalui konsultasi dengan dosen pembimbing dan beberapa dosen bahasa Inggris. Penyusunan modul dan bahan ajar disesuaikan dengan kondisi masyarakat sekitar berdasarkan survey dan observasi secara langsung ke daerah sasaran. Selain itu pada tahap ini juga dilakukan persiapan untuk pelaksanaan penyuluhan, mendata kebutuhan apa saja yang diperlukan seperti menyusun beberapa hal yang akan disosialisasikan, dan lain sebagainya.

5. Rencana Penyuluhan: kegiatan ini bertujuan untuk menyusun jadwal sosialisasi dan penyusunan jadwal pelatihan belajar serta penyesuaian antara jadwal tutor / pemberi materi dengan masyarakat sasaran. Pada tahap ini juga dilakukan pembelian peralatan yang akan digunakan dalam kegiatan penyuluhan. Penyuluhan direncanakan menggunakan metode ceramah sehingga masyarakat bisa mendapatkan informasi yang lebih luas dari tim PEKAN BARIS seperti, pengenalan program,tujuan program, manfaat yang akan diterima oleh masyarakat melalui pelatihan berbahasa Inggris. Membuka kesempatan untuk masyarakat dalam menyampaikan pertanyaan terkait dengan program pelatihan yang akan dilaksanakan.

6. Pelaksaan program pelatihan berbahasa Inggris: merupakan tahapan inti dari pelaksanaan Pekan Baris ini. Adapun metode yang digunakan dalam pelatihan ini adalah

a. Ceramah: pemberian teori secara lisan, tulisan dan tatap muka. Bertujuan memberikan materi secara lebih jelas dan mudah di pahami oleh masyarakat. Suasana metode ceramah dapat dilihat pada lampiran

b. Praktik: penyampaian teori secara praktik dan implementasi dengan meminta peserta berbicara langsung dengan wisatawan asing agar memenuhi kemampuan psikomotorik.

c. Presentasi mandiri, dan diskusi. Dengan bantuan media ajar berupa modul, buku, buku saku, brosur maupun video interaktif. Kegiatan ini berlangsung selama empat bulan dengan jumlah pertemuan sebanyak dua kali perminggu dengan sistem yang akan diterapkan yakni hari pertama pemberian materi pembelajaran, hari kedua 
praktik langsung atau implementasi dari materi yang didapatkan, sejauh mana mereka menguasai materi serta evaluasi jika ada kekurangan. Sistem ini kami terapkan sebagai cara penyesuaian program PEKAN BARIS dengan kehidupan yang dijalani masyarakat yang ada di Desa Pasir Putih pesisir pantai Selong Belanak.

\section{HASIL KEGIATAN}

Proses dan tahapan kegiatan telah dilaksanakan sesuai yang telah direncanakan. Begitupula, jumlah luaran juga dapat tercapai sesuai dengan tahapan masing-masing.

\section{Pembentukan Kelompok Pelatihan}

Telah terbentuk kelompok belajar bahasa Inggris di Selong Belanak di bawah koordinasi Kepala Dusun sebagai pimpinan umum. Berdasarkan pelaksanaan kegiatan pengabdian yang telah dilakukan selama 4 bulan dengan melihat indikator keberhasilan, telah terbentuk beberapa kelompok belajar yang terdiri dari :

a. Kelompok anak-anak: kelompok ini difokuskan untuk menguasai bahasa Inggris mulai dari dasar/ basic, selain itu buku yang digunakan juga disesuaikan dengan kurikulum sekolah agar pelatihan yang di dapat oleh anak-anak tersebut dapat menjadi bekal mereka untuk menerima pelajaran bahasa Inggris yang formal di sekolah. Kelompok ini diketuai oleh salah satu pemuda Selong Belanak yang mengkoordinir terlaksananya kegiatan kelas untuk anak-anak. Kelompok ini juga di bimbing oleh seorang tutor/pemateri yang sudah diseleksi.

b. Kelompok pemuda: kelompok ini difokuskan untuk menguasai speaking/ berbicara bahasa Inggris, hal ini sesuai dengan pekerjaan yang menunjang di daerah tersebut yakni daerah pariwisata sehingga dalam pelatihan kelas ini lebih banyak praktiknya daripada teori serta sering mengadakan study tour atau mendatangkan wisatawan asing untuk melatih kemampuan berbicara bahasa Inggris mereka. Kelompok ini diketuai oleh salah satu pemuda selong belanak yang mengkoordinir terlaksananya kegiatan kelas untuk pemuda. Kelompok ini juga dibimbing oleh seorang tutor/pemateri yang sudah diseleksi.

c. Kelompok orang tua (bapak-bapak dan ibu-ibu): kelompok ini difokuskan untuk menguasai speaking / berbicara bahasa Inggris, hal ini sesuai dengan pekerjaan yang menunjang di daerah tersebut yakni daerah pariwisata juga kondisi masyarakat yang tidak memungkinkan untuk diberikan materi-materi seperti pelajaran di sekolah pada umumnya, sehingga dalam pelatihan kelas ini lebih banyak praktiknya daripada teori serta sering mengadakan praktik langsung untuk menawarkan jasa kepada wisatawan asing sesuai dengan pekerjaan masyarakat setempat. Kelompok ini diketuai oleh salah satu pemuda selong belanak yang mengkoordinir terlaksananya kegiatan kelas untuk orang tua. Kelompok ini juga dibimbing oleh seorang tutor/pemateri yang sudah diseleksi, adapun untuk materi/bahan ajar yang digunakan sudah dibuatkan modul, buku saku khusus percakapan.

\section{Laporan Kemajuan, Laporan Akhir dan Artikel IImiah}

Laporan kemajuan telah diselesaikan dengan baik karena setiap pertemuan pelatihan berbahasa Inggris setiap kegiatan pelaksanaan program didokumentasikan baik dalam bentuk foto video dan catatan harian (logbook) dari setiap anggota untuk mengetahui tingkat pemahaman masyarakat terhadap materi yang disampaikan. Sedangkan, penyusunan laporan akhir dilakukan ketika program pelatihan yang diagendakan telah selesai, sehingga evaluasi terkait keberhasilan dalam keberlanjutan program dapat dilaksanakan secara maksimal. Penyusunan artikel ilmiah dari PKMM PEKAN BARIS telah selesai dilakukan sebagai bentuk dokumentasi tertulis dari kegiatan 
dalam meningkatkan aspek perekonomian masyarakat yang bertempat tinggal di sekitar daerah pariwisata.

\section{PEMBAHASAN}

Seperti diketahui bahasa asing memegang peranan vital dalam industri pariwisata. Pengelolaan pariwisata tanpa didukung dengan adanya keterampilan dan kecakapan berbahasa asing akan menghambat kelancaran dalam memberikan pelayanan terhadap wisatawan yang notabene berasal dari berbagai belahan dunia. Untuk itu memiliki keterampilan berbahasa asing, khususnya bahasa Inggris sebagai bahasa international mutlak diperlukan oleh pelaku pariwisata di Lombok maupun NTB pada umumnya. Bahasa inggris pariwisata digolongkan kedalam English for Specific Purposes (ESP) atau Bahasa inggris untuk tujuan tertentu dalam hal ini untuk tujuan pariwisata atau English for Tourism. Sama halnya dengan sektor lain, English for Tourism mempunyai istilah-istilah dan kosa kata penting tersendiri yang dapat dan perlu untuk dipelajari secara khusus.

Dapat dikatakan bahwa peningkatan mutu dan jenis pelayanan penduduk di sekitar pantai Selong Belanak kepada para wisatawan yang berkunjung merupakan konsekuensi logis dari peningkatan kemampuan mereka dalam berbahasa Inggris yang diperoleh melalui kegiatan pendidikan dan pelatihan. Peningkatan mutu pelayanan kepada para wisatawan merupakan hal yang sesuai dengan hakikat pelatihan yang berorientasi hasil (PBH). Menurut Robinson dan Robinson (dalam Sutarto, 2013:185), pelatihan berorientasi hasil (PBH) adalah pelatihan yang ditujukan untuk menghasilkan tenaga terampil sesuai dengan tuntutan pekerjaan. Hal ini juga sesuai dengan teori Human Capital Invesment yang dikemukakan oleh Becker (dalam Sutarto, 2013:185).

Menurut riset yang dilakukan oleh Wulansari dan Afifulloh (2018), ada beberapa hal yang menjadi rfaktor pendukung masyarakat di pantai-pantai wisata untuk mempelajari bahasa Inggris, yaitu: 1) Minat masyarakat yang tinggi. Hal ini dapat dilihat dari hasil jawaban pertanyaan wawancara yang didapat selama penelitian; 2) Adanya kesadaran akan pentingnya kemampuan bahasa Inggris dikalangan masyarakat sebagai aset pengembang pariwisata sehingga memberikan peluang bagi pemerintah atau pihak lain untuk melakukan tindak lanjut; 3) Bahasa Inggris dianggap sesuatu yang dapat mendukung perkembangan potensi wisata sehingga kesediaan masyarakat berpartisipasi dalam pelatihan bahasa Inggris ada. Dalam hal ini, penelitian di lapangan menunjukan bahwa meskipun beberapa faktor pendukung tersebut di atas ditemukan, namun mereka belum pernah mendapatkan pelatihan baik dari pemerintah maupun inisiatif sendiri dengan mengikuti kursus. Hal ini berdampak tidak hanya pada pada kemampuan bahasa Inggris yang terbatas tetapi juga pada keterbasan pengelolaan potensi wisata pantai yang ada di sekitar mereka.

\section{KESIMPULAN}

Kegiatan pengabdian berupa pelatihan bahasa Inggris bagi penduduk di sekitar pantai wisata Selong Belanak merupakan hal yang penting dan sangat bermanfaat. Hal ini ditunjukkan dengan besarnya antusiasme warga setempat dalam mengikuti pelatihan yang telah dilaksanakan kelompok PKM PEKAN BARIS dengan tahapan dan metode yang telah dilaksanakan.

\section{UCAPAN TERIMA KASIH}

Kegiatan PKM PEKAN BARIS terlaksana berkat pemberian hibah dana oleh Dirjen Belmawa Kemristekdikti tahun 2018. Untuk itu terima kasih kami haturkan untuk Kemristekdikti, Universitas Mataram, dan Dosen Pembimbing PKM Pekan Baris. 


\section{REFERENSI}

Sutarto, 2013. "Strategi Pergeseran Paradigma Pelatihan dari Orientasi Aktivitas di Kelas ke Hasil di Tempat Kerja." Cakrawala Pendidikan. XXXII (2), halaman 183 - 195.

Wulansari Dini \& Afifulloh, M. 2018. "Pemetaan Kebutuhan Bahasa Inggris pada Masyarakat Daerah Potensi Wisata Kabupaten Bangka Provinsi Kepulauan Bangka Belitung." Jurnal Sains Sosial dan Humaniora. Vol. 2 Nomor 1, Maret 2018, hlm. 133 - 144. 